Diabetologia 11, 191-200 (1975)

(c) by Springer-Verlag 1975

\title{
Effect of Duration of Insulin Deficiency on Membrane-Bound and Free Ribosomes from Livers of Diabetic Rats*
}

\author{
F. P. Alford, ${ }^{* *}$ M. E. Millea, E. P. Reaven, R. G. Shorenstein and G. M. Reaven**** \\ Dept. of Medicine, Stanford University School of Medicine and Veterans Administration Hospital, Palo Alto, California, USA
}

Received: July 26, 1974, and in revised form: March 4, 1975

Summary. In order to define the effect of duration of diabetes on hepatic protein synthesis, membrane-bound and free ribosomes were isolated from livers of rats, 3, 7 and 28 days after administration of intravenous streptozotocin $(75 \mathrm{mg} / \mathrm{kg})$. Hepatocytes from the same rats were subjected to ultrastructural quantitative analysis. By day 3 there was a significant loss in the amount of rough endoplasmic reticulum (RER) per volume cytoplasm; however, the normal ratio of membrane-bound ribosomes per unit length of membrane was maintained. These hepatocyte ultrastructural changes continued over the ensuing four weeks. In spite of this decrease in amount of RER, in vitro protein synthetic activity of hepatic membrane-bound polyribosomes was unchanged from controls at three days, and by 28 days protein synthetic activity of bound hepatic ribosomes from diabetic rats was almost twice that of normal controls $(p<.01)$. In contrast to the effect of diabetes on bound ribosomes, there was no change in protein synthetic activity of free polyribosomes isolated from livers of rats, 3, 7 or 28 days after induction of diabetes. Thus, the effect of any given degree of diabetes on hepatic protein synthesis appears to vary with the population of hepatic ribosomes being studied, and with duration of insulin deficiency.

Key words: Insulin deficiency, protein synthesis, hepatic ribosomes, diabetic ribosomes.
Previous studies from our laboratory have indicated that in vitro hepatic protein synthesis was decreased in rats with acute and severe experimental diabetes mellitus $[1,2]$, and that this decrease in protein synthesis was accompanied by a marked loss and disruption of the hepatocyte rough endoplasmic reticulum [2]. Upon further analysis [3] it became clear that the decrease in total hepatic protein synthesis was limited to the bound polyribosome fraction. Furthermore, the decrease in protein synthesis by bound polyribosomes was associated with a reduction in both the amount of rough endoplasmic reticulum (RER) membrane per volume cytoplasm and in the number of bound ribosomes per unit area of RER membrane [3]. In contrast, hepatocyte ribosomes lying free in the cytoplasm were not reduced in number, and isolated free polyribosomes were more active than normal in carrying out protein synthesis [3]. Thus, it was apparent that the response of the two populations of hepatic polyribosomes was quite different. However,

* This work was supported in part by funds from the Veterans Administration, from NHLI Research Grant \#HL 08506, and from the Evelyn L. Neizer Fund. These studies were presented in part at the 33rd Annual Meeting of the American Diabetes Association, Chicago, Ill. June 23-24, 1973.

** Dr. Alford is a Beecham Travelling Fellow of the Royal Australian College of Physicians. Present address is Endocrine Unit, St. Vincent's Hospital, Fitzroy, Victoria, Australia.

*** Dr. Reaven is a Medical Investigator (MRIS \# 7363), Veterans Administration. it was not clear whether these changes in protein synthetic activity of bound and free polyribosomes were characteristic of the effect of diabetes on these ribosomal populations, or whether they represented the effects of insulin deficiency of a particular severity and duration. These questions are important since bound and free ribosomes are believed to have different physiological functions within a cell. Namely, membrane-bound ribosomes synthesize proteins for export, such as albumin, whereas the free ribosome population of a cell elaborate non-export proteins, required for intracellular use $[4,5]$. Any change in relative functions of hepatic bound and free ribosomes may therefore have important consequences to the cell and the whole animal, and may have special relevance in the diabetic state. Thus, in the present study we evaluated the effect of variations in the duration of a less severe degree of insulin deficiency on the function and ultrastructure of the two populations of hepatic ribosomes.

\section{Materials and Methods}

\section{Experimental Protocol}

Female Sprague-Dawley rats, weighing 190-200 $\mathrm{g}$, were housed in pairs and given food and tap water ad lib. Room lighting was controlled on a $12 \mathrm{hr}$ dark: $12 \mathrm{hr}$ light regime. Animals were weighed regularly and the amount of food and fluid ingested was recorded. 
Diabetes mellitus was produced by an intravenous injection of streptozotocin $(75 \mathrm{mg} / \mathrm{kg}$ body weight in $\mathrm{pH} 4.2$ citrate buffer) after a $15 \mathrm{hr}$ overnight fast [6]. Control rats were injected with an equal volume of buffer solution. Animals ate and drank freely until time of death. Rats were killed by decapitation 3,7 or 28 days after injection. At the time of death only animals with a similar degree of severity of diabetes were selected for study (Table 1). Selection was based
$\mathrm{KCl} ; 0.004 \mathrm{M} \mathrm{MgCl}_{2} ; 0.25 \mathrm{M}$ sucrose ${ }^{1}$ ), aliquoted and stored at $-20^{\circ} \mathrm{C}$ until time of assay.

\section{Incubation of Ribosomes}

Protein synthetic activity of isolated ribosomes directed by endogenous messenger was estimated by incorporation of ${ }^{3} \mathrm{H}$-phenylalanine ${ }^{2}$ into TCA precipitable radioactivity; the rate of incorporation of labeled amino acid into protein being directly pro-

Table 1. Data on control and diabetic rats. Diabetes was induced by an intravenous injection of 75 mg/kg streptozotocin and rats were sacrificed 3,7 and 28 days later. Number in parenthesis refers to number of animals in each group

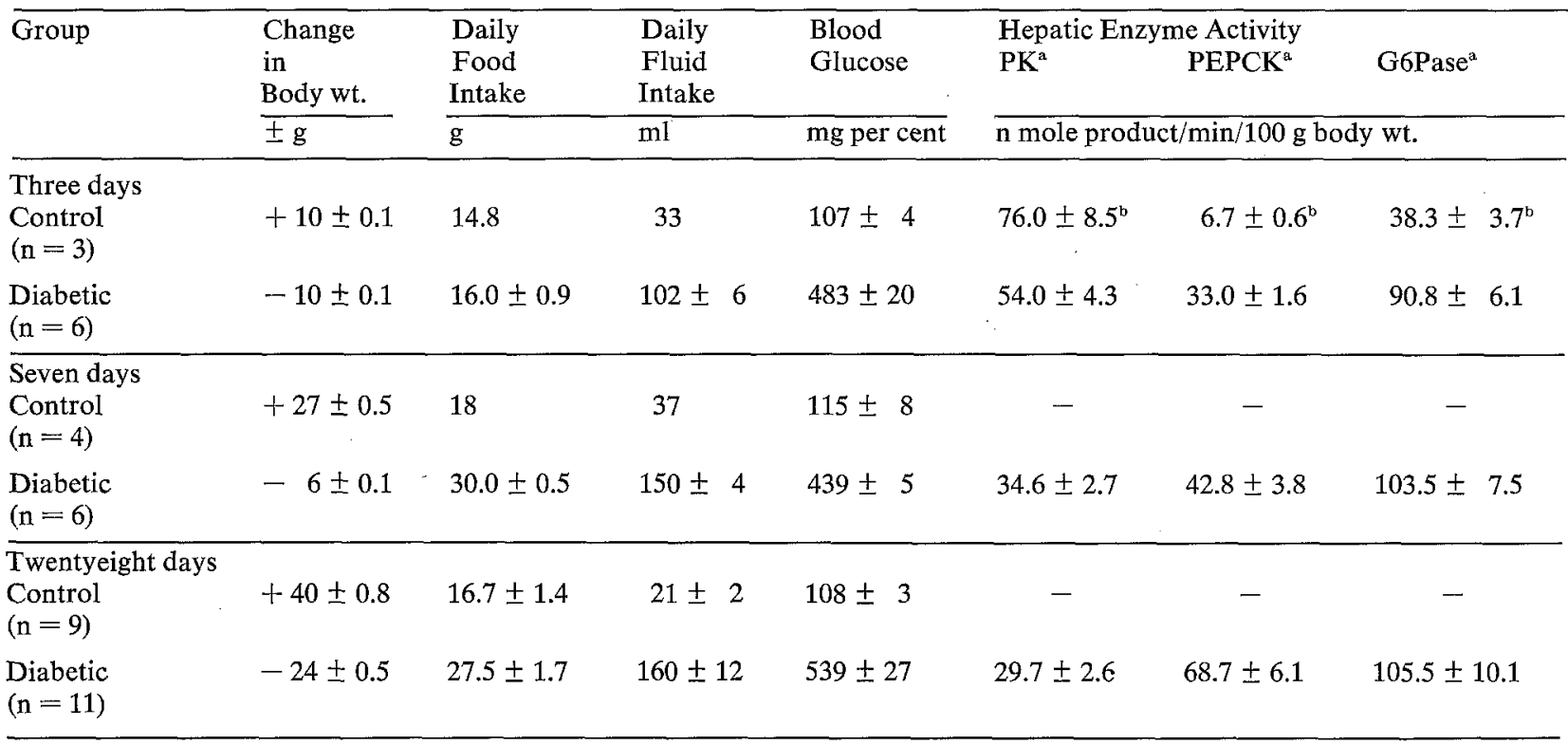

${ }^{a}$ Abbreviations: PK, pyruvate kinase; PEPCK, phosphenol pyruvate carboxykinase; G6Pase, glucose-6-phosphatase.

b Enzyme activities of control animals were similar on each day and therefore control values have been pooled from days 1,3 and 28 .

upon the presence of similar blood glucose levels, weight loss, daily food and fluid intake [6], and activity in postnuclear $(500 \mathrm{xg})$ supernatant fractions of key glycolytic and gluconeogenic enzymes [7]. For diabetic rats, pyruvate kinase activity fell $(P<0.01)$ whereas the activities of phosphoenol pyruvate carboxykinase and glucose-6-phosphatase rose $(P<$ $0.001)$. This resulted in the rejection of approximately $25 \%$ of injected rats.

\section{Isolation of Membrane-Bound and Free Ribosomes}

Membrane-bound and free polyribosomes were prepared from post nuclear $(500 \mathrm{xg})$ supernatant fractions (PNS) of liver homogenates by discontinuous sucrose gradients $[8,9]$, in the presence of ribonuclease inhibitor [10] as previously described [3]. The isolated bound and free ribosomes were suspended in TKM-S $0.25(0.05 \mathrm{M}$ Tris-HCl, $\mathrm{pH} 7.6 ; 0.025 \mathrm{M}$ portional to the amount of ribosomal RNA used. The assay was performed as previously described from this laboratory $[1,3,11]$, but a Sephadex G-25 liver cell cytosol enzyme preparation from normal rat (300 $\mu \mathrm{g}$ protein $/ 50 \mu \mathrm{g}$ ribosomal RNA) was used [12] instead of the $\mathrm{pH} 5.0$ enzyme preparation. Optimum activity of the assay was obtained with $7.0 \mathrm{mM} \mathrm{Mg}{ }^{++}$, but relative differences in amino acid incorporation persisted for all $\mathrm{Mg}^{++}$concentrations between 3 and $18 \mathrm{mM}$. Protein synthetic activity was expressed as $\mathrm{cpm}$ of ${ }^{\mathrm{s}} \mathrm{H}$-phenylalanine incorporated into protein per milligram ribosomal RNA.

For assays using polyuridylic acid (polyU) as artificial messenger, "stripped" monosomes were employ-

1 Schwarz-Mann ultrapure, ribonuclease-free, sucrose was used for all sucrose containing solutions.

${ }^{2}$ New England Nuclear Corp., L'H-phenylalanine, 20 $\mathrm{Ci} / \mathrm{mMole}$. 
ed $[1,3]$. Following preincubation of ribosomes in a complete amino acid-incorporating system containing pH 5.0 enzyme preparation [13], duplicate aliquots were furnished with either polyU $(100 \mu \mathrm{g} / 50 \mu \mathrm{g}$ ribosomal RNA) or an equivalent volume of water, G25 cytosol enzymes, the ATP energy generating system and ${ }^{3} \mathrm{H}$-phenylalanine and incubated for a further 90 min. Protein synthetic activity of the ribosomes was again expressed as cpm per milligram ribosomal RNA; the net activity being calculated by subtracting the $\mathrm{cpm}$ for the sample without polyU from cpm for the sample with polyU. Although differences in amino acid incorporation existed between ribosomes from control and diabetic animals at all magnesium concentrations tested $\left(4-22 \mathrm{mM} \mathrm{Mg}^{++}\right)$, peak levels were obtained with both types of ribosomes at $15 \mathrm{mM}$ $\mathrm{Mg}^{++}$.

For both assay systems, comparisons between ribosomes from normal and diabetic animals were made with samples isolated on the same day and incubated in the same assay.

\section{Morphometric Studies}

Ultrastructural morphometric analysis were carried out on the same tissues used for study of in vitro protein synthetic. Details of the preparation of liver samples for electron microscopy have been recently reported from this laboratory [2, 3]: quantitative characterization of the RER was based on the methods of Loud [14] and Weibel [15].

In general, periportal hepatocytes obtained from control and experimental animals were inspected for overall ultrastructural characteristics, and then subjected to two separate techniques in order to quantitate and characterize the RER. Four randomly selected nucleated cells from each of 4 rats from each experimental group were selected for analysis $[2,3]$. An estimation of the amount of RER present in the hepatocyte cytoplasm (expressed as surface area of RER/volume cytoplasm) and the number of bound ribosomes per area of RER membrane (expressed as number of ribosomes/surface area RER) was obtained. From these data, the total number of bound ribosomes per volume cytoplasm could be derived for average hepatocytes from diabetic and control rats [3].

\section{Analytical Procedures}

Blood glucose was measured from glucose oxidase impregnated paper strips [16]. Ribosomal RNA was estimated by the method of Fleck and Munro [17] and the protein content of PNS and cell cytosol by the procedure of Lowry [18]. Activity in postnuclear $(500 \mathrm{xg})$ supernate fractions of the glycolytic and gluconeogenic enzyme were assayed as follows: pyruvate kinase (PK) was estimated by a modification [19] of the 2, 4 dinitrophenylhydrazine method. Phosphoenolpyruvate carboxykinase (PEPCK) activity was assayed by the method of Ballard and Hanson [20], utilizing the rate of incorporation of ${ }^{14} \mathrm{C}$ bicarbonate into oxalo-acetate. Glucose-6-phophatase (G6P) was measured by the method of Segal and Washko [21] on PNS pretreated with sodium desoxycholate $^{3}$. For this latter assay, glucose production was quantitated using a glucostat $\mathrm{kit}^{4}$. Enzyme activities were expressed as nmol product per $100 \mathrm{~g}$ body weight.

Differences between experimental and control groups were assessed by Student's-t-test.

\section{Results}

\section{General Observations}

Following the administration of streptozotocin, diabetes developed rapidly. As depicted in Fig. 1, blood glucose levels in diabetic rats rose to approximately $500 \mathrm{mg} / 100 \mathrm{ml}$ by day 3 , and remained about this level for the ensuing weeks. By the end of the first week the diabetic rats were hyperphagic, con-

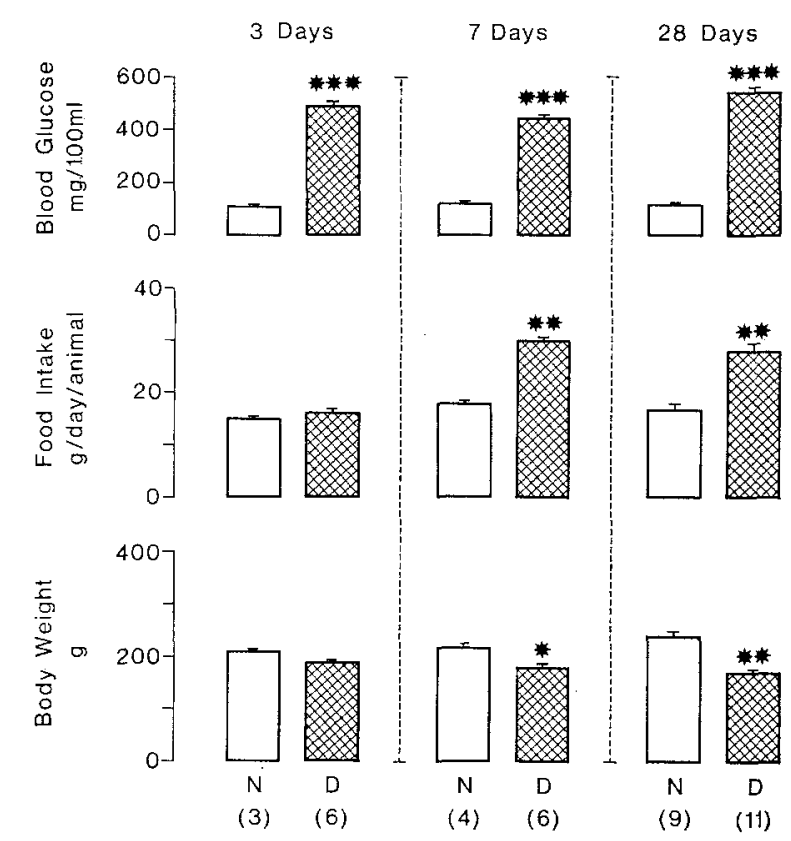

Fig. 1. Mean ( $\pm \mathrm{SE}$ ) changes in blood glucose concentration, daily food intake and body weight of normal (N) and diabetic (D) rats over the four weeks following streptozotocin. $P<0.05$ denoted by *, $<0.01$ by **, and $<0.001$ by ****

\footnotetext{
3 Nutritional Biochem. Corp.

4. Worthington Biochem. Corp.
} 


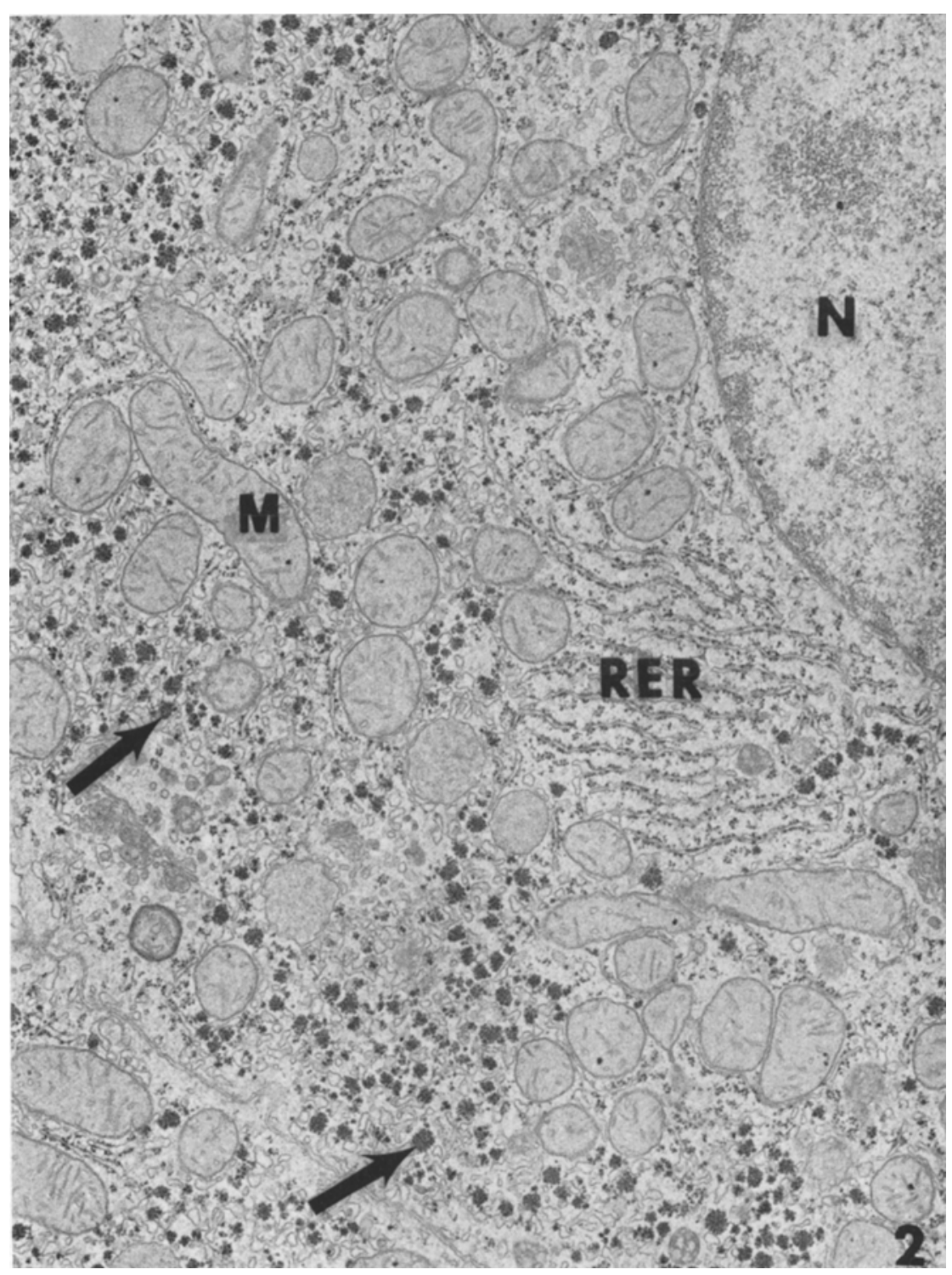

Fig. 2. Low power electron micrograph of hepatocyte from control rat showing normal distribution of rough endophasmic reticulum (RER), nucleus $(\mathrm{N})$, mitochondria $(\mathrm{M})$, and glycogen (arrows). X 14,000

suming almost twice the control intake. Despite the increase in daily food intake of diabetic rats, weight loss of over $20 \mathrm{~g}$ occurred by the fourth week. Dietary intake and blood glucose levels of control rats remained constant, and these rats gained approximately $40 \mathrm{~g}$ during the same period.

Fig. 2 is an electron micrograph of a normal hepatocyte, and Fig. 3 a comparable view of a hepatocyte from a rat after 3 days of insulin deficiency. Note in Fig. 3 the loss of glycogen, the swelling of the mitochondria, and reorganization of the RER. These changes in hepatic cell ultrastructure were not uniformly distributed among the periportal cells; some cells appeared to be more affected than others by the diabetic state. By 28 days of insulin deficiency (Fig. 4) the above changes had progressed somewhat, with a slightly greater degree of disruption of intracellular RER architecture. The aggregation and number of free polysomes did not appear altered at any time after the induction of diabetes (Fig. 5).

\section{Effect of Duration of Insulin Deficiency on Protein Synthesis Directed by Endogenous mRNA}

The effect of duration of diabetes on in vitro protein synthetic activity of isolated bound and free polyribosomes, 3, 7 and 28 days after streptozotocin administration is shown in Fig. 6 and 7 and Table 2 . Although there was no change in the protein synthetic activity of bound hepatic ribosomes from rats with diabetes of three days duration, protein synthetic activity began to increase after seven days, and was clearly elevated 28 days after induction of the diabetic 
Fig. 3. Low power electron micrograph of hepatocyte from rat given streptozotocin three days earlier. Note redistribution of profiles of rough endoplasmic reticulum (arrowheads). Mitochondria (M) are enlarged as compared to controls. Glycogen is diminished in amount. Nucleus $(\mathbf{N})$. X 14,000

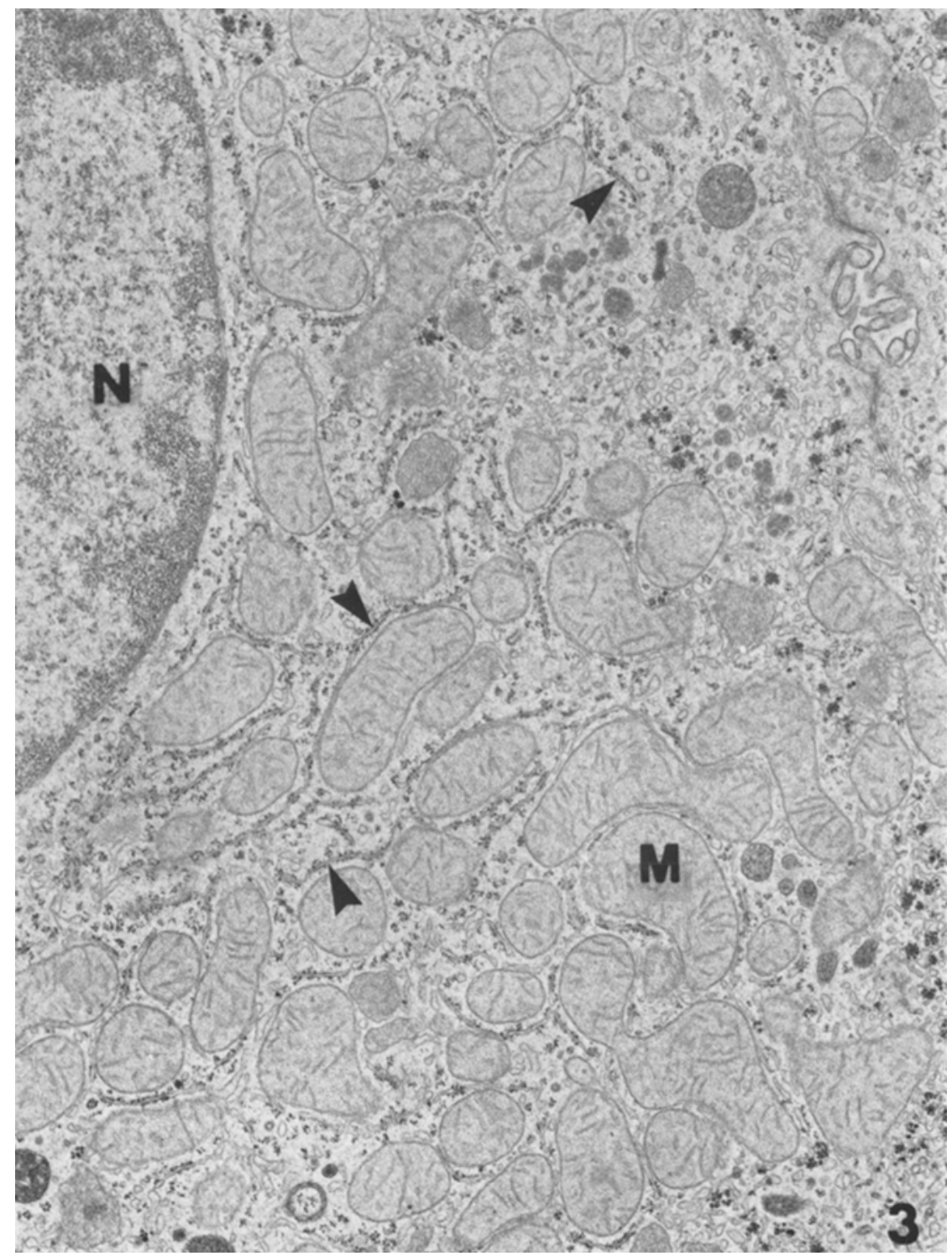

state (Fig. 6, Table 2). In contrast, insulin deficiency had no significant effect on the protein synthetic activity of free hepatic ribosomes (Fig. 7, Table 2).

\section{Effect of Duration of Diabetes on PolyU Directed Protein Synthesis}

One possible explanation for the increased protein synthetic activity of bound ribosomes that occurred with duration of diabetes could be related to a change in these ribosomes which led them to become intrinsically more efficient in copying mRNA. This increased efficiency of translation might also be observed when the bound ribosomes, stripped of endogenous messenger, are copying the artificial messenger, polyU. This possibility was tested by comparing the rate of polyU-directed incorporation of amino acid into protein by hepatic ribosomes from normal and 28 day diabetic rats. The results are shown in Fig. 8, and indicate that bound ribosomes from 28 day-diabetic rats are also more active than ribosomes from control rats when amino acid incorporation is directed by artificial messenger RNA. In contrast, protein synthetic activity of "stripped" free hepatic ribosomes from normal and diabetic rats remained equal when directed by polyU; the ratio of diabetic/normal being $1.05 \pm 0.08$.

\section{Quantitative Changes in RER in Relationship to the Duration of Insulin Deficiency}

The effect of diabetes on hepatocyte RER membrane and its attendant population of bound ribosomes was quantified by measuring the area of RER 


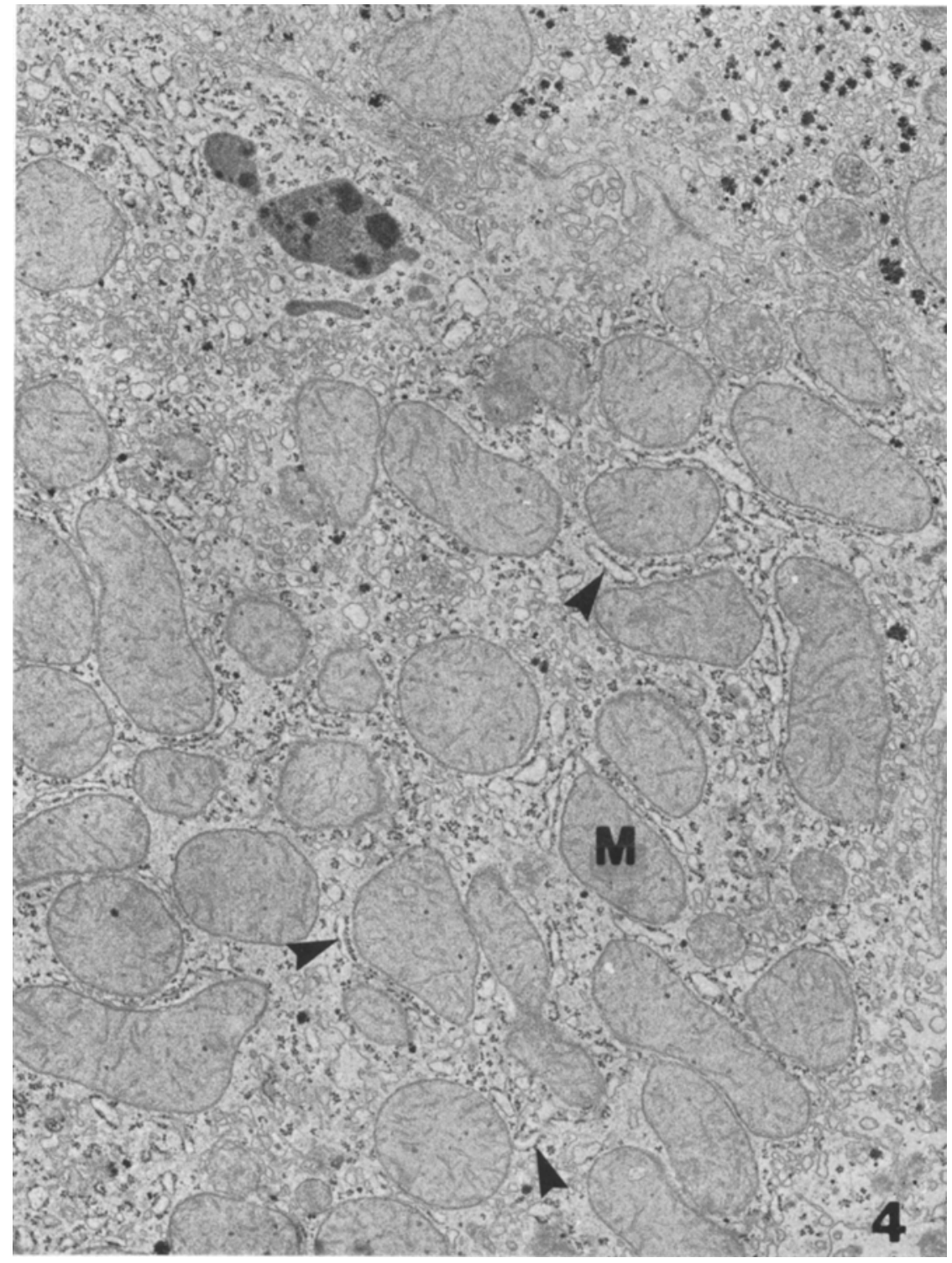

Fig. 4. Low power view of typical hepatocyte from rat given streptozotocin $(75 \mathrm{mg} / \mathrm{kg})$ four weeks earlier. Profiles of rough endoplasmic reticulum (arrowheads) appear to be fewer in number and show swelling and different distribution than found in normal hepatocyte shown in Fig. 2 . Mitochondria (M) are enlarged as compared to control. Glycogen is greatly diminished in amount. $\mathrm{X}$ 14,000 membrane per cell volume as well as the number of bound ribosomes per area of RER membrane in hepatocytes from normal and diabetic rats (Table 3). Such analysis deals separately with the issues of how much RER membrane is present in the cell and how many ribosomes are present per unit membrane. The area of RER membrane per volume cytoplasm (Table 3 , Column 1) was reduced by approximately $25 \%$ $(P<0.01)$ three days after the induction of diabetes. This reduction in amount of RER continued over the next weeks, with the total area of RER membrane being reduced by approximately $35 \%$ by four weeks (Table 3, Column 1).

In contrast to these findings, the number of bound ribosomes per area of RER membrane was unchanged, whether at 3, 7 or 28 days (Fig. 5) after the strep- tozotocin administration (Table 3, Column 2). Finally, the average number of membrane-bound ribosomes per unit volume of hepatocyte cytoplasm was obtained. These figures (Table 3, Column 3) were derived from the data recorded in Columns 1 and 2. Since the number of ribosomes per area of RER membrane remained constant, the reduction in total number of bound ribosomes per cytoplasmic volume reflected the reduction in amount of RER membrane alone and was in the order of $30-35 \%$ throughout the study.

\section{Discussion}

The results presented in this study highlight the fact that the effects of insulin deficiency on rat hepatic ribosomal protein synthesis are very complex. In the 
Fig. 5. Higher power view of portion of cytoplasm from hepatocyte of rat given streptozotocin four weeks earlier. Despite the fact that cisternac of rough endoplasmic reticulum (arrowheads) appear to be swollen, membrane-attached ribosomes are plentiful. Note also that free polysomes (arrows) are present in large numbers in cytoplasm. X 39,200

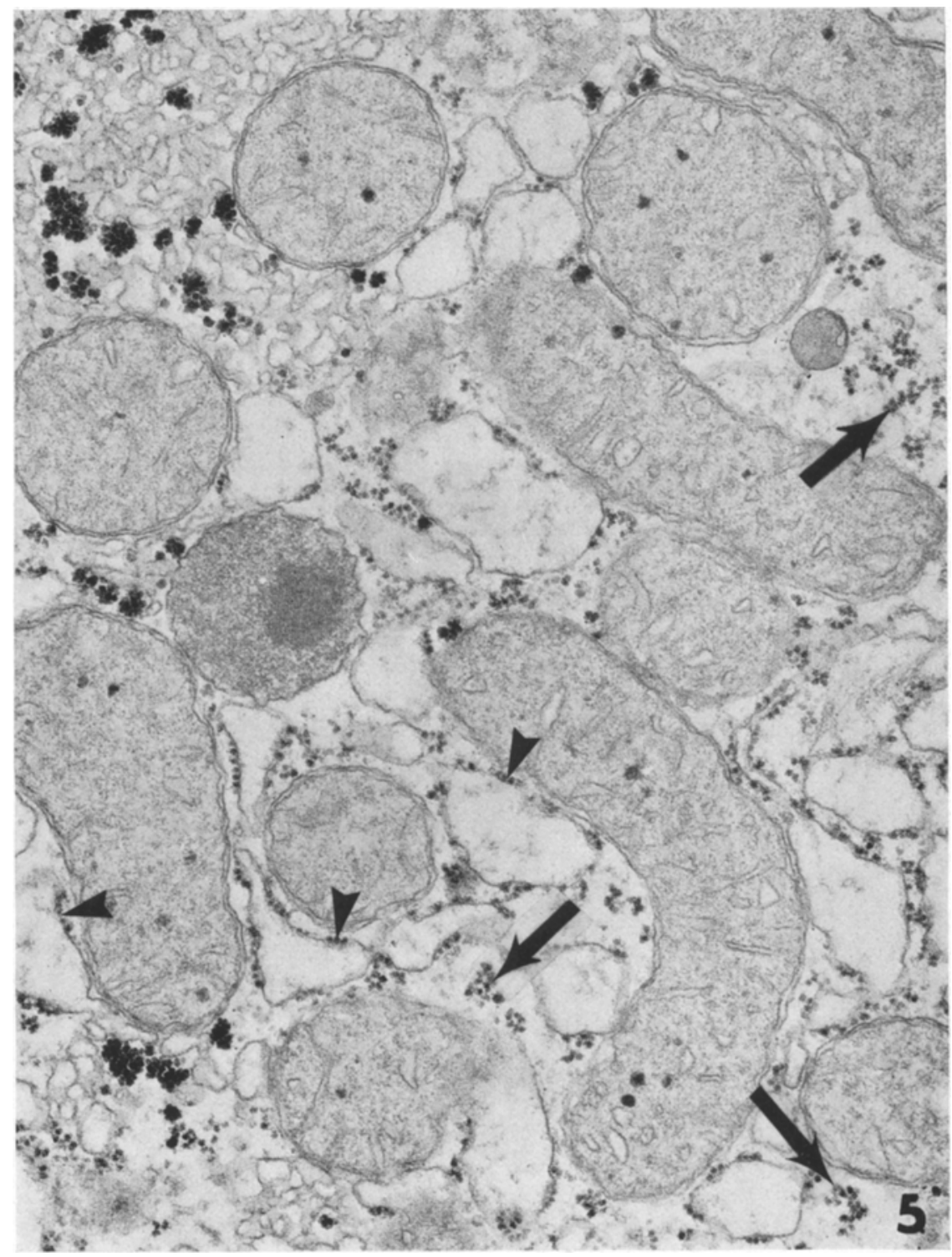

first place, these studies point out that the two different ribosomal populations of the liver respond differently to the same degree of diabetes (Fig. 6 and 7). Second, these results indicate that the effect of insulin deficiency on hepatic protein synthesis varies with the severity of the metabolic defect. Thus, as shown previously, extremely severe diabetes ${ }^{5}$ of three days duration resulted in decreased protein synthesis by bound polyribosomes [3]. In contrast, the current study demonstrates that less severe diabetes ${ }^{6}$ of three

${ }_{5}^{5}$ Induced by $100 \mathrm{mg} / \mathrm{kg}$ streptozotocin and associated with blood glucose $650 \mathrm{mg} \%$, severe weight loss of $36 \mathrm{~g}$ over 3 days, anorexia and severe malaise, and death at $4-5$ days [3].

${ }^{6}$ Induced by $75 \mathrm{mg} / \mathrm{kg}$ streptozotocin, with mean blood glucose $488 \mathrm{mg} \%$, mean weight loss of $10 \mathrm{~g}$ by 3 days, normal or increased appetite and prolonged survival $[6,7]$. days duration has no effect on the protein synthetic capacity of bound polyribosomes. Finally, these results indicate that the duration of the metabolic defect can also modify protein synthesis. For instance, in the current study in vitro protein synthesis of hepatic bound polyribosomes was unchanged as compared to normal after three days of insulin deficiency; however, there appeared to be an actual increase in protein synthesis one week later, and by four weeks the protein synthetic activity of the bound polyribosomes from livers of diabetic rats was unequivocal. Thus, it is clear that the effects of insulin deficiency on hepatic protein synthesis depends upon the population of hepatic ribosomes studied, the severity of the metabolic lesion, and the duration of the diabetic state.

Although these results demonstrate the variable 
Table 2. Protein synthetic activity of membrane-bound and free hepatic ribosomes isolated from control and diabetic rats. Animals were sacrificed 3, 7 and 28 days after the streptozotocin ( $75 \mathrm{mg} / \mathrm{kg}$ body wt.) injections. Ribosomes $(50 \mu \mathrm{g}$ ribosomal RNA/tube) were incubated for $30 \mathrm{~min}$ at $37^{\circ} \mathrm{C}$, in $500 \mu \mathrm{l}$ media containing 29 non-radioactive amino acids $(0.08 \mu \mathrm{mol})$, $\left({ }^{3} \mathrm{H}\right)$-phenylalanine, GTP $(0.18 \mu \mathrm{mol}), A T P(1.0 \mu \mathrm{mol})$, phosphoenol-pyruvate $(4.1 \mu \mathrm{mol})$, pyruvate kinase $(20 \mu \mathrm{g})$, dithiothreitol $(0.4 \mathrm{umol}), \mathrm{Mg}^{++}(7.0 \mathrm{mM}), 0.04 \mathrm{M}$ Tris- $\mathrm{HCl}$ buffer $p H 7.8$, and Sephadex G25 liver cell cytosol $(300 \mu \mathrm{g})$ and pH $5(500 \mu g)$ fractions from normal rat. Protein synthetic activity was expressed as cpm/mg ribosomal RNA (mean $\pm S E M)$

\begin{tabular}{|c|c|}
\hline \multirow[t]{2}{*}{ Group } & Protein Synthetic Activity \\
\hline & Bound $\quad$ Free \\
\hline
\end{tabular}

\begin{tabular}{lll}
\hline Three day & & \\
Control & $32.9 \pm 0.4$ & $31.9 \pm 2.8$ \\
Diabetic & $36.6 \pm 3.2$ & $32.2 \pm 4.2$ \\
\hline Seven day & & \\
Control & $24.4 \pm 2.0$ & $20.6 \pm 4.2$ \\
Diabetic & $33.3 \pm 3.2$ & $26.5 \pm 1.0$ \\
\hline Twenty eight day & & \\
Control & $22.4 \pm 2.6$ & $19.1 \pm 2.5$ \\
Diabetic & $44.4 \pm 6.0$ & $21.7 \pm 3.5$ \\
\hline
\end{tabular}

Table 3. Morphometric analysis of the effects of chronic diabetes (streptozotocin $75 \mathrm{mg} / \mathrm{kg}$ ) on the ribosome $(R)$ and membrane components of the rough endoplasmic reticulum (RER) of rat hepatocytes (Mean $\pm S E M)$

\begin{tabular}{llll}
\hline $\begin{array}{l}\text { Experimen- } \\
\text { tal Group }\end{array}$ & $\begin{array}{l}\text { Area } \\
\text { RER/volume } \\
\text { cytoplasm } \\
\text { ( } \mu^{2} \text { RER/ } / \mu^{3} \\
\text { cytoplasm) } \\
\text { I }\end{array}$ & $\begin{array}{l}\text { Number } \\
\text { bound ribo- } \\
\text { somes/area } \\
\text { RER } \\
\left(\mathrm{R} / \mu^{2} \text { RER) }\right. \\
\text { II }\end{array}$ & $\begin{array}{l}\text { Bound riboso- } \\
\text { mes/volume } \\
\text { cytoplasm } \\
\left(\mathrm{R} / \mu^{3} \text { cyto- }\right. \\
\text { plasm) } \\
\text { III }\end{array}$ \\
\hline $\begin{array}{l}\text { Control } \\
(\mathrm{n}=4)\end{array}$ & $5.26 \pm 0.18$ & $369 \pm 15$ & $1941 \pm 133$ \\
$\begin{array}{l}\text { Diabetic } \\
(3 \text { days) } \\
(\mathrm{n}=3)\end{array}$ & $4.02 \pm 0.48^{\mathrm{b}}$ & $361 \pm 33$ & $1452 \pm 221^{\mathrm{a}}$ \\
$\begin{array}{l}7 \text { days } \\
(\mathrm{n}=4)\end{array}$ & $3.38 \pm 0.22^{\mathrm{c}}$ & $391 \pm 17$ & $1322 \pm 140^{\mathrm{a}}$ \\
$\begin{array}{l}28 \text { days } \\
(\mathrm{n}=4)\end{array}$ & $3.45 \pm 0.23^{\mathrm{c}}$ & $407 \pm 33$ & $1404 \pm 151^{\circ}$ \\
\hline
\end{tabular}

a $p<0.05$ compared to normal controls

${ }^{b} p<0.005$ compared to normal controls

c $p<0.001$ compared to normal controls

nature of the response of hepatic ribosomes to the insulin deficient state, they also provide considerable insight into the mechanisms responsible for these changes. Thus, the previously described increase in protein synthesis of free ribosomes from livers of rats

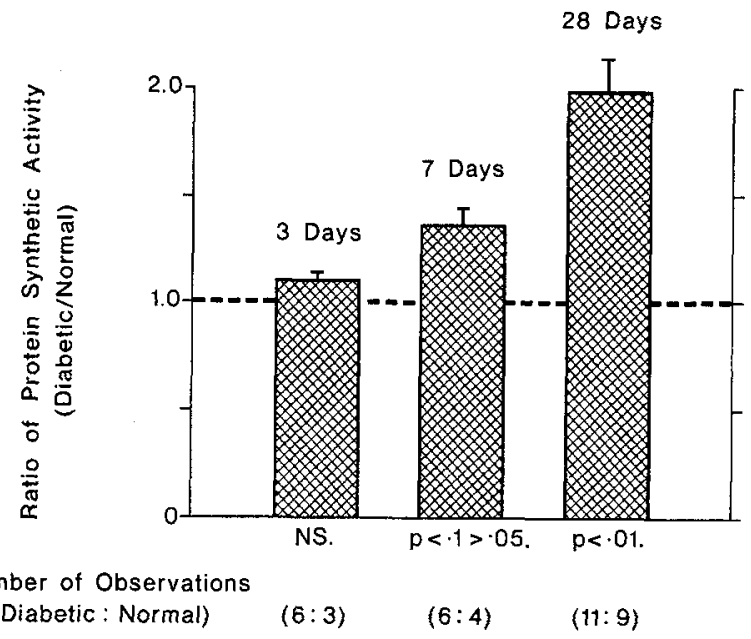

Fig. 6. Mean ( $\pm \mathrm{SE}$ ) protein synthetic activity of bound hepatic polyribosomes isolated from normal and diabetic rats. Animals were sacrificed 3,7 and 28 days after intravenous streptozotocin $(75 \mathrm{mg} / \mathrm{kg})$, and results are expressed as the ratio of protein synthetic activity of diabetic to normal. A ratio of 1.0 would indicate that the protein synthetic activity of the diabetic and control groups were equal. The number of observations are listed in parentheses below each histogram

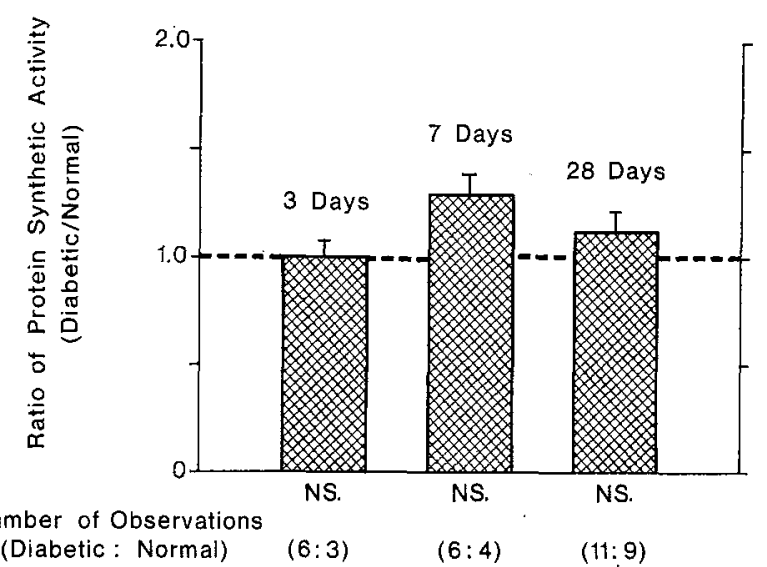

Fig. 7. Mean ( $\pm \mathrm{SE}$ ) protein synthetic activity of free hepatic polyribosomes isolated from normal and diabetic rats. Animals were sacrificed 3,7 and 28 days after intravenous streptozotocin $(75 \mathrm{mg} / \mathrm{kg})$ and the results are expressed as the ratio of protein synthetic activity of diabetic to normal. A ratio of 1.0 would indicate that the protein synthetic activity of the diabetic and control groups were equal. The number of observations are listed in parentheses below each histogram

with severe diabetes of three days duration [3], and the increase in activity of bound hepatic ribosomes from rats with more chronic and less severe diabetes seen in the current study, both appear to be due to the behaviour of ribosomes which are structurally intact and intrinsically more efficient in copying messenger. Although we did observe a moderate decrease in the number of bound ribosomes per volume hepato- 


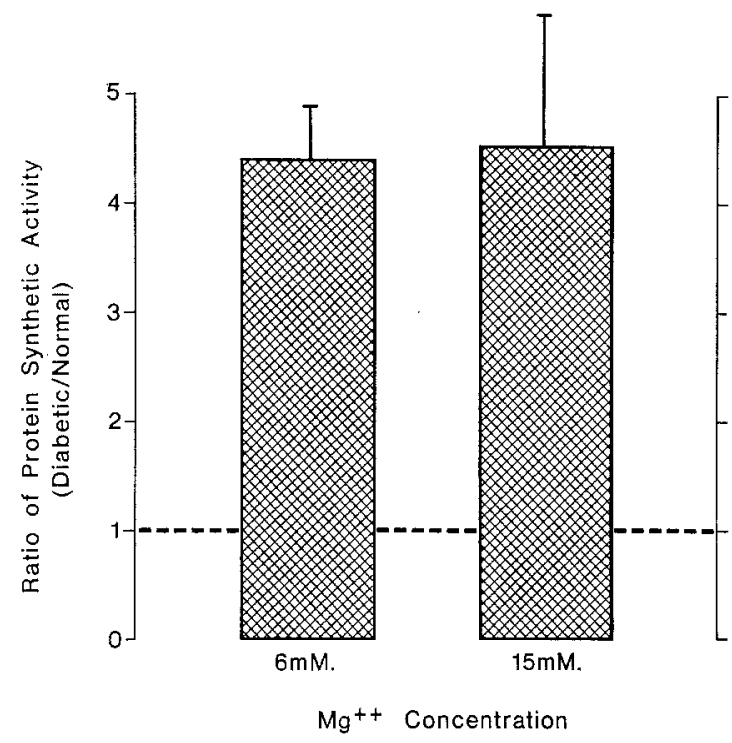

Fig. 8. Protein synthetic activity of hepatic bound polyribosomes isolated from rats with diabetes of 28 days duration as compared to normal. In vitro protein synthesis was directed by artificial messenger, polyU, using monosomes "stripped" of endogenous mRNA by pre-incubation of ribosomes prior to the addition of artificial messenger (see Methods). Results are expressed as the ratio of protein synthetic activity of diabetic to normal, and are derived from protein synthetic activity, expressed as cpm/mg ribosomal RNA: control group, 11,200 and 54,100 at 6 and $15 \mathrm{mM} \mathrm{Mg}$ : versus, diabetic group, 49,000 and 245,600 at 6 and $15 \mathrm{mM} \mathrm{Mg}{ }^{++}$concentrations, respectively

cyte cytoplasm after four weeks of diabetes, the remaining population of bound ribosomes had a normal ratio of ribosomes per unit length of RER membrane. Furthermore, protein synthesis was increased in these bound ribosomes when directed by either endogenous mRNA or polyU. Similarly, no ultrastructural alterations were observed in the population of free ribosomes present in livers of animals with severe diabetes of three days duration. And, the increase in protein synthesis was seen with both natural and synthetic messenger [3].

On the other hand, a very different mechanism seems to be responsible for the decrease in protein synthesis that occurs with bound ribosomes from liver of rats with very severe diabetes of three days duration [3]. In this instance, there are widespread ultrastructural changes, characterized by a drastic reduction in RER and a marked decrease in the number of ribosomes bound to the RER membrane [3]. These results suggest that there is disruption of the normal membrane ribosome mRNA unit, and that it is this disaggregation which is responsible for the defect in protein synthesis.

Thus, it is apparent that the effects of diabetes on ribosomal function are extremely complex. Not only do the responses of the two ribosomal populations isolated from the one tissue differ according to the severity and duration of the diabetic state; but the ability of diabetic ribosomes to support protein synthesis is also influenced by the tissue of origin of the ribosomes. For example, muscle ribosomes isolated from rats on the 3rd day of diabetes incorporate less amino acids into protein [22] whereas kidney ribosomes from 3 day diabetic rats show increased protein synthetic activity [11], as compared to their respective controls. Muscle and kidney ribosomal preparations consist of predominantly free ribosomes, and it is clear therefore that hepatic and kidney free ribosomes from diabetic rats show increased protein synthetic activity, in contrast to free ribosomes from muscle of diabetic rats, which demonstrate reduced activity. The mechanisms for these divergent effects of diabetes on ribosomal function are unknown. Furthermore, the earlier investigations on hepatic ribosomes from diabetic animals from this $[1,2]$ and other laboratories [23], which demonstrated overall decreased protein synthesis of total liver ribosomes and in which no attempts were made to separate the two hepatic ribosomal populations, probably gave an oversimplified and therefore incomplete picture of the effects of diabetes on overall hepatic ribosomal function.

In conclusion, the present results only provide a restricted view as to the total impact of experimental diabetes on hepatic protein synthesis. The net effect of insulin deficiency on in vivo protein synthesis represents a complex interplay of a great number of additional factors which modulate protein synthetic activity, including both the specific effects of insulin lack, as well as the consequences of the metabolic response of the organism to the diabetic state. That is, the level of protein synthesis in vivo reflects the interplay of many factors; ribosomes, transfer RNA, amino acids, soluble cytosol factors and membrane phenomena $[24,25]$, all of which may be influenced by the diabetic state. However within these limitations, the results of this study help to clarify the precise nature of the effects of experimental insulin deficiency on the in vitro protein synthetic behaviour of both populations of hepatic ribosomes, as well as providing information as to the mechanisms responsible for these effects. Future studies will have to be aimed at defining the physiological implications of these effects of diabetes on hepatic ribosomal structure and function.

Acknowledgements. We wish to thank Friederike Boost, Janet Alford and Celia Moreno for their expert technical assistance and Fred Conrad for his helpful advice. 


\section{References}

1. Tragl, K. H., Reaven, G. M.: Effect of experimental diabetes mellitus on protein synthesis by liver ribosomes. Diabetes 20, 27--32 (1971)

2. Reaven, E. P., Peterson, D. T., Reaven, G. M.: The effect of experimental diabetes mellitus and insulin replacement on hepatic ultrastructure and protein synthesis. J. clin. Invest. 52, 248-262 (1973)

3. Peterson, D. T., Alford, F. P., Ueyama, I., Reaven, E. P., Reaven, G. M.: Characteristics of membrane bound and free hepatic ribosomes from insulin deficient rats. I. Acute experimental diabetes mellitus. J. clin. Invest. 52, 32013211 (1973)

4. Redman, C. M.: Biosynthesis of serum proteins and ferritin by free and attached ribosomes of rat liver. $\mathbf{J}$. biol. Chem. 244, 4308-4315 (1969)

5. Takagi, M., Tanaka, T., Ogata, K.: Functional differences in protein synthesis between free and bound polysomes of rat liver. Biochim. biophys. Acta (Amst.) 217, 148-158 (1970)

6. Junod, A., Lambert, A. E., Stauffacher, W., Renold, A. E.: Diabetogenic action of streptozotocin: Relationship of dose to metabolic response. J. clin. Invest. 48, 2129-2139 (1969)

7. Murphy, E. D., Anderson, J. W.: Tissue glycolytic and gluconeogenic enzyme activities in mildly and moderately diabetic rats: Influence of tolbutamide administration. Endocrinology 94, 27-34. (1974)

8. Blobel, G., Potter, V. R.: Studies on free and membrane bound ribosomes in rat liver. I. Distribution as related to total cellular RNA. J. molec. Biol. 26, 279-292 (1967)

9. Blobel, G., Potter, V. R.: Studies on free and membrane bound ribosomes in rat liver. II. Interaction of ribosomes and membranes. J. molec. Biol. 26, 293-302 (1967)

10. Blobel, G., Potter, V. R.: Relation of ribonuclease and ribonuclease inhibitor to the isolation of polysomes from rat liver. Proc. nat. Acad. Sci. (Wash.) 55, 1283-1288 (1966)

11. Peterson, D. T., Greene, W. C., Reaven, G. M.: The effect of experimental diabetes on kidney ribosomal protein synthesis. Diabetes 20, 649-654 (1971)

12. Richardson, A., McGown, E., Henderson, L. M., Swan, P. B.: In vitro amino acid incorporation by the post mitochondrial supernatant of rat liver. Biochim. biophys. Acta (Amst.) 254, 468-477 (1971)

13. Hogland, M. B., Stephenson, M. L., Scott, J. F., Hecht, L. C., Zamecnik, P. C.: A soluble ribonucleic acid intermediate in protein synthesis. J. biol. Chem. 231, 241-257 (1958)
14. Loud, A. V.: A quantitative stereological description of the ultrastructure of normal rat liver parenchymal cells. J. Cell Biol. 37, 27-46 (1968)

15. Weibel, E. R.: Stereological principles for morphometry in electron microscopic cytology. Int. Rev. Cytol. 26, 235-302 (1969)

16. Mazzaferri, E. L., Stillman, G., Lanese, R. R., Keller, M. P.: Use of test strips with colour meter to measure bloodglucose. Lancet 1970 I, 331-333

17. Fleck, A., Munro, H. N.: The precision of ultraviolet absorption measurements in the Schmidt-Thannhauser procedure for nucleic acid estimation. Biochim. biophys. Acta (Amst.) 55, 571-583 (1962)

18. Lowry, O. H., Rosebrough, N. J., Farr, A. L., Randall, R. $\mathrm{J}$.: Protein measurement with the folin phenol reagent. $\mathrm{J}$. biol. Chem. 193, 265-275 (1951)

19. Kimberg, D. V., Yelding, K. L.: Pyruvate kinase. Structural and functional changes induced by diethylstilbestrol and certain steroid hormones. J. biol. Chem. 237, 32333239 (1962)

20. Ballard, F. J., Hanson, R. W.: Phosphoenol pyruvate carboxykinase and pyruvate carboxylase in developing liver. Biochem. J. 104, 866-871 (1967)

21. Segal, H. L., Washko, M. E.: Studies of liver glucose 6phosphotase. Solubilization and properties of the enzyme from normal and diabetic rats. J. biol. Chem. 234, 19371941 (1959)

22. Wool, I. G., Stirewalt, W. S., Kurihara, K., Low, R. B., Bailey, P., Oyer, D.: Hormones and metabolic function. Mode of action of insulin in regulation of protein synthesis in muscle. Recent Progr. Hormone Res. 24, 139213 (1968)

23. Manchester, K. L.: Effect of insulin on protein synthesis. Diabetes 21 (supp1. 2), 447-452 (1972)

24. Baliga, B. S., Pronczuk, A. W., Munro, H. N.: Regulation of polysome aggregation in a cell-free system through amino acid supply. J. molec. Biol. 34, 199-218 (1968)

25. Nolan, R. D., Hoadland, M. B.: Cytoplasmic control of protein synthesis in rat liver. Biochim. biophys. Acta. (Amst.) 247, 609-620 (1971)

F. Alford, M. D.

Endocrine Unit

St. Vincent's Hospital

Victoria Parade, Fitzroy

Victoria

Australia 